\title{
DERECHOS EN CONFLICTO. HONOR, LIBERTAD DE EXPRESIÓN Y VIDA COTIDIANA EN LA ESPAÑA DEL SIGLO XIX
}

\section{RIGHTS IN CONFLICT. HONOUR, FREEDOM OF SPEECH AND DAILY LIFE IN NINETEENTH CENTURY SPAIN}

\author{
Raquel Sánchez \\ Universidad Complutense de Madrid
}

\begin{abstract}
SUMARIO: I. INTRODUCCIÓN. II. LA LEY, EL HONOR Y LA PRENSA. III. EL HONOR DE LOS PARTICULARES. 3.1. El honor de los varones. 3.2. El honor de los profesionales y de las empresas. 3.3. El honor de las mujeres. IV. EL HONOR DE LAS AUTORIDADES. V. EL DUELO COMO ALTERNATIVA. VI. CONCLUSIONES. VII. BIBLIOGRAFÍA
\end{abstract}

\section{Resumen:}

Este artículo pretende estudiar las colisiones entre dos derechos protegidos por las constituciones y la legislación española en el siglo XIX: el honor y la libertad de expresión. Desde una perspectiva histórica, se trata de analizar de qué manera las leyes, la jurisprudencia y las percepciones de los contemporáneos nos explican los conflictos entre ambos derechos. Asimismo, se estudiará el papel del Estado como mediador en los conflictos surgidos y por qué algunos individuos siguieron utilizando el duelo como instrumento para limpiar su reputación en un lugar de recurrir a los tribunales.

\begin{abstract}
:
This article aims to study the conflicts between two rights protected by the constitutions and legislation in the 19th century Spain: the right to honour and the freedom of speech. From a historical perspective, the text tries to analyse how the laws, the jurisprudence and the perceptions of contemporaries explain to us the collision between both rights. Also, it studies the role of the State as mediator in the conflicts arisen in that context and asks why some individuals continued to use duel as a way to clean up their reputation instead of appealing to the courts.
\end{abstract}

Palabras clave: Honor, Prensa, Duelo, Masculinidad, Libertad de expresión, Legislación

Key Words: Honour, Press, Duel, Manliness, Freedom of Speech, Law

\section{INTRODUCCIÓN}

A partir del siglo XVIII se produjo en Europa una resignificación del viejo concepto del honor barroco en favor otras acepciones que evidencian un cambio 
de mentalidad patente entre finales del siglo y los inicios del XIX ${ }^{1}$. En este proceso, el concepto fue adquiriendo unos perfiles que se movieron entre la consideración del honor como un código moral de conducta ${ }^{2}$ y su plasmación en un sentido burgués de la vida que apelaba a la propia dignidad de cada sujeto reflejada en su independencia económica y politica. Se trataría, en definitiva, de una nueva forma de entender la identidad del sujeto apoyada en el desarrollo de su individualidad que, proyectada socialmente por medio de su imagen pública, tenía en su desempeño profesional y económico una marca de estatus social cuya importancia venía dada por el reconocimiento de las demás personas ${ }^{3}$. Se trataba de un código de valores entendido en función del discurso de la masculinidad burguesa que se iba a convertir en normativo en el siglo XIX para el cual el valor físico, la lealtad, el dominio de sí mismo y la autonomía moral constituían los caracteres definidores del varón ${ }^{4}$. Esta nueva forma de entender el honor iba a necesitar unos mecanismos de protección legal que la ampararan frente a la expansión, reconocida constitucionalmente, de la libertad de imprenta, de prensa y de expresión, es decir, frente al desarrollo de la esfera pública. Sin embargo, la convivencia entre el derecho al honor y a la libertad de expresión no siempre fue fácil. En ese contexto, el papel del Estado tuvo una gran importancia porque se convirtió en elemento de mediación en los conflictos surgidos entre los sujetos. La regulación, por parte del poder público, de los limites de estos derechos por medio de la legislación especial de prensa e imprenta y de los códigos penales implicaba, además, la interiorización de los principios de la legalidad del Estado por parte de la ciudadanía.

1 Véase: James Bowman, Honor. A History, Encounter Books, Nueva York, 2006. Algunos especialistas, como Frank Henderson Stewart, consideran que este proceso puede datarse, incluso, antes del XVIII (Honor, University of Chicago, Chicago/Londres, 1994). En el estudio del honor, aunando los enfoques antropológico e histórico, son de referencia los trabajos de Julien Pitt-Rivers, Antropología del honor o politica de sexos. Ensayos de antropología mediterránea, Crítica, México D.F., 1979 y Carlos Maiza Ozcoidi, "La definición del concepto del honor. Su entidad como objeto de investigación”, Espacio, Tiempo y Forma, Serie IV, t. 8, 1995, pp. 191-209. Un análisis de su desarrollo desde una perspectiva histórica, en Pablo Ortega del Cerro, "Del honor a la honradez: un recorrido por el cambio de valores sociales en la España de los siglos XVIII y XIX”, en Cuadernos de Ilustración y Romanticismo, n² 24, 2018, pp. 597-618.

2 Alexander Welsh, What is Honor? A Question of Moral Imperatives, Yale University Press, New Haven/Londres, 2008.

3 Véase al respecto: Charles Taylor, Fuentes del yo. La construcción de la identidad moderna, Paidós, Barcelona, 2006. Taylor contrapone una identidad premoderna, propia del Antiguo régimen, frente a la identidad moderna, producto de la Ilustración, que se define por la particularidad de cada individuo frente a los demás. La especificidad de cada sujeto se refleja en la exteriorización pública de sus realizaciones en el contexto de la vida cotidiana.

4 Sobre esta cuestión véanse, entre otros, George L. Mosse, The image of man: the creation of modern masculinity, Oxford University Press, Oxford, 1996; John Tosh, Manliness and Masculinities in Nineteenth Century Britain: essays on gender, family, and empire, Routledge, Londres, 2016 (2005); Anne Marie Sohn, "Sois un Homme!" La construction de la masculinité au XIXe siècle, Seuil, Paris, 2009; y Alain Corbin (dir.), Histoire de la virilité. 2. Le triomphe de la virilité. Le XIXe siècle, Seuil, París, 2011. Para el caso español, puede consultarse: María Sierra, "Entre emociones y politica: la historia cruzada de la virilidad romántica", Rúbrica Contemporánea, vol. 4, n $n^{\circ}$ 7, 2015 y Nerea Aresti, Médicos, donjuanes y mujeres modernas: los ideales de feminidad y masculinidad en el primer tercio del siglo XX, Universidad del País Vasco, Bilbao, 2001. La proyección de este discurso en las clases trabajadoras en Jesús de Felipe Redondo, "Masculinidad y movimiento obrero español: las identidades masculinas obreras y el trabajo femenino, 1830-1870", Historia, trabajo y sociedad, nº 8,2017 , pp. 65-85. 
El objetivo de este trabajo es conocer, a partir del análisis histórico, de qué forma se produjo el diálogo entre las leyes sobre los delitos contra el honor y sobre la libertad de expresión y la mentalidad de la sociedad española del siglo XIX. Nos interesa aquí, más que los enfrentamientos entre la política y la prensa de la España liberal filtrados por la cultura del honor, la vivencia cotidiana de las agresiones a la reputación de los individuos, de qué forma se producían estas y bajo qué parámetros la ley protegía la reputación de los sujetos. Para ello, se recurrirá tanto a la percepción de los contemporáneos como a las sentencias judiciales que resolvieron estos conflictos. Se comenzará con un somero repaso a la forma en la que tanto la legislación penal como la relativa a la libertad de imprenta trataron estos delitos. Después se entrará de lleno en el análisis del concepto del honor compartido por varones y mujeres a través de las sentencias judiciales resultado de los conflictos de intereses desatados a causa de agresiones verbales o escritas a la reputación personal. Esta documentación nos muestra hasta qué punto era significativa la presencia diaria de esos elementos de dignidad personal que fueron esgrimidos por personas de ambos sexos, por compañias y empresas y por el propio Estado, para hacer prevalecer tanto su reputación como su lugar en la jerarquía social ${ }^{5}$. Finalmente, se tratará la legislación relativa al duelo, en tanto que la práctica del duelo por parte de las élites masculinas de este periodo fue una alternativa a lo que se consideraba una limitación de la legislación en materia de protección del honor de las personas.

\section{LA LEY, EL HONOR Y LA PRENSA}

Con mayor o menor generosidad, todas las constituciones españolas del siglo XIX reconocieron en su articulado las libertades relacionadas con la libre expresión de las opiniones. La libertad de expresión, con carácter genérico, y la libertad de prensa e imprenta más concretamente, fueron, así, pilares del sistema político liberal. Eso no quiere decir que se convirtieran en derechos absolutos, pues su ejercicio podía limitarse por razones diversas, en particular por razones de orden politico, pues fueron los delitos politicos el centro de las preocupaciones de los gobiernos, algo que resulta evidente al analizar la legislación sobre esta

5 Las sentencias que se analizan proceden de la información proporcionada por los comentarios de Salvador Viada y Vilaseca al código de 1870 y del cotejo de la jurisprudencia del Tribunal Supremo con este código llevada a cabo por Juan Antonio Hidalgo García. Con anterioridad al código de 1870 no es frecuente encontrar entre los juristas referencias a sentencias concretas que nos permitan llevar a cabo un análisis detenido. Viada y Vilaseca suele hacer mención a la Gaceta de Madrid en que se publicó la sentencia que comenta, aunque sus referencias no son siempre correctas. En este artículo se ha remite a la Gaceta cuando se ha podido constatar que la sentencia apareció publicada, efectivamente, el día indicado por Viada. En los casos erróneos, se alude al libro de este jurista. Juan Antonio Hidalgo no indica la Gaceta en la que aparecieron las sentencias que comenta. Véanse: Salvador Viada y Vilaseca, Código penal reformado de 1870: con las variaciones introducidas en el mismo por la ley de 17 de julio de 1876: concordado y comentado, Imp. de Manuel G. Hernández, Madrid, 1885; y Juan Antonio Hidalgo García, El Código Penal conforme a la doctrina establecida por el Tribunal Supremo, Imp. de la Revista de Legislación, Madrid, 1909, vol. II. Los comentarios al Código de 1870 del gran jurista de la Restauración, Alejandro Groizard y Gómez de la Serna, no remiten a sentencias concretas, aunque tienen gran interés por su trabajo comparativo con la anterior legislación española y con los códigos contemporáneos europeos y americanos (El Código penal de 1870 concordado y comentado por D. (Alejandro) Groizard y Gómez de la Serna, tomo V, Esteban Hermanos impresores, Salamanca, 1894). 
materia 6 . Sin embargo, la protección del honor también estuvo en el punto de mira de los legisladores. El ejercicio de los derechos relacionados con la libertad de expresión colisionaba con una de las mayores angustias de los individuos de la sociedad posrevolucionaria: la difamación. El miedo al escándalo y, por consiguiente, a la pérdida de la reputación se convirtió en el acicate mayor para unos individuos, los varones de clase media y alta, que veían amenazado continuadamente su honor ${ }^{7}$. Por lo tanto, en el proceso de reinterpretación del concepto que se produjo en Occidente en el siglo XIX se hacía necesario convertir el honor en un bien jurídico protegido por la legislación frente a uno de los derechos más importantes del liberalismo clásico: la libertad de prensa.

Los códigos penales de la España del siglo XIX no recogieron los delitos vinculados al honor con la denominación de "difamación", sino con la de calumnias e injurias, según la gravedad de los mismos ${ }^{8}$. Si tomamos los diccionarios de la Real Academia Española de 1817 y de 1884 para ver cuál era la definición usual de ambos términos en la época que nos ocupa, comprobaremos su distinta proximidad a las definiciones dadas por los códigos y la forma en la que, a lo largo del tiempo, se ha ido produciendo una comunicación entre la precisión jurídica de los términos con la explicación lingüística de los mismos. En 1817 la Academia definía la calumnia como "La acusación falsa hecha maliciosamente para causar daño". En 1884 ya se precisaba de esta forma: "Imputación falsa de un delito de los que dan lugar a procedimiento de oficio". Es decir, en las décadas finales del siglo, la Academia ya había incorporado el significado jurídico de la palabra "calumnia" para sancionar su uso común entre la ciudadanía. Con respecto a la injuria, la RAE decía lo mismo en 1817 y en 1884: "Afrenta, agravio, ultraje de obra o de palabra", mostrando menor precisión de la que, por poner un ejemplo, ofrecía el código de 1870 cuando definía el delito de injuria de la siguiente forma: "Es injuria toda expresión proferida o ejecutada en deshonra, descrédito o menosprecio de otra persona". El sentido convencional que la Academia dio al término "injuria" no revelaba la importancia de una conducta que, por sus consecuencias en distintos niveles, iba a tener una gran relevancia en la convivencia social y politica ${ }^{9}$. Por otra parte, y antes de entrar en detalle en el análisis de ambos delitos, conviene traer a colación un resto del pasado claramente impregnado del significado barroco del honor que, si bien

\footnotetext{
6 Véase al respecto el clásico libro de Alicia Fiestas Loza, Los delitos políticos (1808-1936), Universidad de Salamanca, Salamanca, 1977.

7 Sobre el escándalo y sus consecuencias en la reputación de los personajes públicos, véase el dossier dirigido por Isabel Burdiel y Pol Dalmau i Palet, La imagen pública del poder. Escándalos y causas célebres en Europa (siglos $X I X-X X)$, Historia y politica: Ideas, procesos y movimientos sociales, $\mathrm{n}^{\circ} 39,2018$.

8 Hay que señalar que, también juridicamente, el significado de la palabra "honor" difería si se aplicaba sobre un sujeto masculino o sobre un sujeto femenino. En líneas generales, se considera al honor masculino una cualidad activa que el individuo defendia frente a agentes externos, mientras que el femenino era un honor pasivo, que había de ser defendido públicamente por los varones de los que la mujer dependia material o afectivamente y que tenía que ver con la virtud sexual. El honor femenino se hallaba asociado a la palabra "honestidad". De hecho, los códigos penales dedicaban un título a los "Delitos contra el honor" (calumnias e injurias) y otro a los "Delitos contra la honestidad", que eran el adulterio, la violación, el rapto, el estupro y la corrupción de menores.
}

9 Véase al respecto el mapa de diccionarios históricos de la Real Academia Española: http://web.frl.es/ntllet/SrvltGUILoginNtlletPub (consulta: 8.4.2019). 
quedó recogido en el código de 1822, desapareció de los siguientes códigos penales. Se trata de la pena de infamia, que tantas resonancias tiene de una vieja mentalidad en la que el honor estamental, la pureza de sangre y la ortodoxia religiosa constituian la base del respeto social a los individuos. La infamia implicaba la pena de vergüenza pública y la degradación del individuo como ciudadano. Se podía aplicar a delitos diversos, tanto de carácter político como económico ${ }^{10}$.

Al llevar a cabo un análisis de los delitos contra el honor en la legislación española del siglo XIX se hace necesario poner en relación los códigos penales con la legislación sobre prensa e imprenta ${ }^{11}$. En el decreto de 10 de noviembre de 1810 ya se hacía alusión a las prevenciones que se tomarian en el caso de publicación de "libelos infamatorios" y de "escritos calumniosos". Este decreto, al igual que el resto de la legislación gaditana, marcaba una diferencia al respecto de la legislación anterior sobre imprenta que se mantendría a lo largo de todo el siglo XIX y que evidenciaba un cambio de mentalidad: solo se considerarian lesionados los bienes objeto de protección jurídica cuando se hubieran difundido dichos impresos, no antes ${ }^{12}$. No será hasta el Trienio Liberal cuando veamos una regulación más clara de los delitos contra el honor. Esta regulación tendría lugar con el código penal de 1822, que en su título segundo "De los delitos contra la honra, fama y tranquilidad de las personas", desarrollaba esta cuestión entre los artículos 699 y 718. En las definiciones de ambos delitos, la publicidad de la injuria o de la calumnia constituía un elemento agravante. Por tanto, toda difamación publicada por los periódicos se hallaba comprendida en este elemento agravante, aunque tan solo el hecho de haber sido proferida en público implicaba una pena mayor. Dependiendo de las circunstancias, además, y según el artículo 699, la pena podía alcanzar los seis años de reclusión. Más ajustado al tipo de delitos que se podían cometer en la prensa se hallaba el título noveno, titulado "De los delitos y culpas de los impresores, libreros y otras personas en el abuso de la libertad de imprenta", en el que el responsable podía ser acusado de reo de libelo infamatorio y calumnioso, con la pena comentada anteriormente ${ }^{13}$. Es

10 La pena de infamia consistía en lo siguiente: "El reo a quien se le imponga la pena de infamia perderá, hasta obtener la rehabilitación, todos los derechos de ciudadano; no podrá ser acusador sino en causa propia, ni testigo, ni perito, ni albacea, ni tutor ni curador sino de sus hijos y descendientes en línea recta, ni árbitro, ni ejercer el cargo de hombre bueno, ni servir en el ejército ni armada, ni en la milicia nacional, ni tener empleo, comisión, oficio, ni cargo público alguno", Código penal español, decretado por las Cortes en 8 de junio, sancionado por el Rey y mandado promulgar en 9 de julio de 1822, Imprenta Nacional, Madrid, 1822, artículo 74, p. 16.

11 Contamos, a este respecto, con dos estudios juridicos sobre estas cuestiones: Jaime Mira Benavent, Los límites penales a la libertad de expresión en los comienzos del régimen constitucional español, Tirant lo Blanc, Valencia, 1995; y Alejandro de Pablo Serrano, Los delitos contra el honor en el derecho penal español y en el derecho comparado, Universidad de Valladolid, Valladolid, 2014. Desde una perspectiva histórica y centrado en cuestiones políticas, es imprescindible el trabajo de Demetrio Castro Alfin, Los males de la imprenta. Politica y libertad de prensa en una sociedad dual, Centro de Investigaciones Sociológicas, Madrid, 1998.

12 Jaime Mira Benavent, Los límites penales, op. cit., p. 51. La Constitución de Cádiz protegía la libertad de imprenta en su artículo 371. El decreto que complementa la legislación gaditana sobre libertad de imprenta es el de 10 de junio de 1813. Sobre estas cuestiones, véase también: Ignacio Fernández Sarasola, “Opinión pública y 'Libertades de expresión' en el constitucionalismo español (1726-1845)", Historia constitucional: Revista Electrónica de Historia Constitucional, nº 7, 2006.

13 Código penal español, decretado por las Cortes en 8 de junio, sancionado por el Rey y mandado promulgar en 9 de julio de 1822, op. cit., artículos 592-604, pp. 119-121. 
especialmente interesante el artículo 595 que se concentraba en la responsabilidad "de los abusos" y la atribuía a los autores o editores de los impresos, quienes debian firmar el original del texto, que debía quedar en poder del impresor para disponer de testimonio en el caso de que se procediera a incoar un procedimiento. El Código de 1822 bebía directamente del decreto de 22 de octubre de 1820, que sentó las bases jurídicas sobre la libertad de imprenta en la primera experiencia liberal española. Sin embargo, y por lo que se refiere a la responsabilidad de los impresores y autores, el código reforzó las garantías con respecto a la protección del honor en un momento histórico en que la prensa estaba cobrando una importancia de primera magnitud ${ }^{14}$.

La legislación de imprenta previa al Código penal de 1848 siguió recogiendo la protección a "la reputación y conducta privada de los individuos", como señalaba la real orden de 1 de junio de 1834. Esta real orden introdujo, además, un elemento que se mantendría posteriormente y que mostraba el diálogo entre la legislación y la realidad política y periodística del país. Señalaba este texto jurídico que se perseguirian los libelos injuriosos y difamatorios que atacaran la reputación de los individuos, aunque no se les designara con sus nombres y se utilizaran "anagramas, alegorías" o cualquier otro medio. La prensa de los años treinta aún no utilizaba de forma generalizada la imagen gráfica por el limitado desarrollo de la técnica, por lo que la real orden no alude a la caricatura como soporte para la difamación, cosa que sí encontraremos en la legislación posterior. Los decretos de 10 de abril de 1844 y de 6 de julio de 1845 ya hablaban de la difusión de injurias y calumnias "por la imprenta, litografia, grabado o cualquier otro medio de publicación". Más evidente sería aún durante los códigos posteriores, cuando ya se aluda claramente al uso de caricaturas como potencial vehículo para cometer el delito de injurias ${ }^{15}$. La legislación sobre imprenta del reinado isabelino incidía claramente en lo que se denominaba "los excesos de la prensa", que habían llegado a invadir "el sagrado hogar doméstico", como decía el decreto de 10 de abril de 1844 . Pese a todo, el centro de interés seguía hallándose en los delitos políticos derivados de la libertad de prensa, por lo que los delitos contra el honor fueron siendo relegados cada vez más hacia el derecho común, quedando excluidos de la legislación especial sobre prensa e imprenta ${ }^{16}$.

El código penal de 1848 (endurecido en algunas disposiciones con la reforma de 1850) siguió la misma tónica, aunque precisando más en los delitos asociados a la reputación pública de los individuos. Ya se habla de los "delitos contra el honor" (no contra la honra y la fama, como en 1822) y del "falso testimonio y la acusación y denuncia calumniosas"17. La definición que más se ajusta a la

\footnotetext{
14 Jaime Mira Benavent, Los limites penales, op. cit., p. 127.

15 Así aparece en el código de 1848 reformado en 1850 y en el de 1870 (títulos XI y X, respectivamente, "Delitos contra el honor").

16 Es interesante consignar que, con algunos matices, la legislación sobre libertad de imprenta y prensa mantuvo la tendencia, ya comentada, de considerar las calumnias e injurias a particulares como delitos privados (juzgables, por tanto, por la legislación ordinaria), mientras que las calumnias e injurias a los monarcas y otras personalidades de carácter politico entraban de lleno en la categoria de delitos de imprenta, juzgables, por tanto, por medio de una legislación propia por su naturaleza de delitos políticos.
}

17 Es interesante recalcar el matiz que se encuentra detrás de este cambio nominal, pues la expresión "honra y fama" hace alusión al carácter privado (honra) y al público (fama) de la reputación del individuo, mientras que "honor" engloba ambas facetas de la imagen de las 
difamación es la del delito de injuria que afecta "a la deshonra y descrédito de la otra persona" (artículos 368 del código de 1848 y 379 de la reforma de 1850). Se establecen gradaciones a las que se ajustan las penas, introduciéndose la de destierro en el caso más grave. De nuevo, la publicidad se convierte en elemento agravante. En los muy interesantes comentarios contenidos en la edición que del código se hizo en Barcelona en el mismo año de 1848, destaca un hecho significativo que, leído en la clave del código del honor, viene a apoyar la idea de que el agredido por un ataque a su reputación en la prensa no se sintiera especialmente protegido por la legislación, razón esgrimida por los defensores del duelo como mecanismo para solventar conflictos de honor. Escribían los juristas sobre el artículo 375 lo siguiente: "Según este artículo, las calumnias e injurias hechas en periódicos no serán delitos de imprenta, sino comunes, sujetos como tales a los tribunales ordinarios. Nótese, además, que los manuscritos volantes solo están comprendidos en la disposición cuando se hayan comunicado a más de diez personas, cuya circunstancia deberá probar el injuriado"18. Es decir, la carga de la prueba recaía sobre la persona ofendida.

Igualmente, y según su artículo 381, el Código de 1848 indicaba que "Nadie será penado por calumnia o injuria, sino a querella de la parte ofendida. E1 culpable quedará relevado de la pena impuesta, mediando perdón de la misma". Se vuelve, por tanto, a la misma idea: los ataques al honor no constituian un delito especial (como los delitos políticos) sino un delito común o, en su caso, una falta que podian ser perdonada por el ofendido. Los únicos delitos de imprenta, por lo que respecta a la publicación de injurias y calumnias, eran, por tanto, los delitos políticos, como señaló el jurista Joaquín Francisco Pacheco ${ }^{19}$. Eso sí, habiéndose demostrado la falsedad de las acusaciones, el editor del periódico que las hubiera publicado debía publicar también la "satisfacción o sentencia condenatoria, si lo reclamare el ofendido" (artículo 377). Es decir, se relativizaba el carácter de la ofensa, convirtiéndola en algo subjetivo que quedaba en manos del ofendido reclamar, perdonar o perseguir judicialmente. De nuevo, tal ambigüedad no podia sino reforzar la importancia del código de honor en unos individuos que consideraban que la ley común no atendía a las necesidades de aquellos que tenian una imagen pública que proteger.

Con la revolución de 1868 tuvieron lugar importantes cambios. En primer lugar, el decreto de 23 de octubre de 1868 puso fin a la legislación especial sobre la imprenta. Los delitos de imprenta pasarian a ser regulados por la legislación

personas en una sola palabra. Se hace patente, así, la identificación entre las facetas públicas y privada de la imagen de los individuos, forzando, de esta forma, la interiorización de los valores sociales como valores privados y domésticos.

$18 \mathrm{El}$ artículo 375 en Código penal de España, sancionado por S.M. en 19 de mayo de 1848, y reformado según el real decreto de 30 de junio de 1850, Manuel Aurí, Barcelona, 1850, p. 95. Los comentarios en: Código penal de España, sancionado por S.M., enmendado con arreglo a los reales decretos de 21 y 22 de septiembre de 1848 y comentado por D.J.S. y D.A. de B., abogados de los tribunales del Reino y del Ilustre Colegio de esta ciudad, Imprenta de D. Ramón Martín Indar, Barcelona, 1848, p. 162. Estos comentarios tienen un interés especial porque se hicieron antes del endurecimiento del código en 1850.

19 Joaquín Francisco Pacheco, El Código penal concordado y comentado, Imprenta de la Viuda de Perinat y Compañia, Madrid, 1856 (2 ${ }^{\text {a }}$ edición), vol. 1, pp. 122-123. De esta forma, se establecía una distinción, como dice Mira Benavent, entre los "delitos de imprenta" y los "delitos comunes cometidos a través de la imprenta", distinción que se mantendrá hasta 1870 (J. Mira Benavent, Los limites penales, op. cit., p. 192). 
penal ordinaria, la del nuevo código. El Código penal de 1870 precisaba más la forma por la que los delitos de imprenta podian repercutir en la reputación de los individuos. Hay que tener en cuenta, como se acaba de decir, que este código se elaboró en pleno Sexenio democrático, periodo en el que las libertades de imprenta, de asociación y de expresión se ensancharon considerablemente, con las consecuencias que ello podia traer consigo. Este texto sigue a las modificaciones de 1850 por lo que respecta a los delitos contra el honor, es decir, las calumnias y las injurias, y lo adapta a la Constitución de 1869. Sin embargo, refleja con más claridad que los anteriores la realidad de un mundo periodístico en crecimiento. Es sabido que los códigos penales han de legislar a posteriori, una vez que se han observado las tendencias punibles de una sociedad, por lo que puede decirse que el código de 1870 es una radiografia de la España de los años anteriores, filtrada por la ampliación de las libertades que trajo consigo la revolución de 1868. Si, como se decía líneas más arriba, no se observan grandes cambios por lo que se refiere a los delitos de calumnias e injurias, sí se introducen novedades en relación a la publicación de la retractación ante acusaciones falsas en la prensa (en especial en título I, libro III: "De las faltas de imprenta y contra el orden público" y en especial en el capítulo I: "De las faltas de imprenta" ${ }^{20}$. Finalmente, y por lo que se refiere a la legislación sobre imprenta, tras la restrictiva ley de 1879, se promulgó la ley de 26 de julio de 1883 (conocida como ley Gullón), que fue la legislación más liberal de todo el siglo. Por lo que respecta a la protección del honor, la ley incluía varios artículos que conminaban a los periódicos a insertar comunicados de retractación en el caso de ofensas causadas a autoridades, corporaciones y particulares ${ }^{21}$. En definitiva, en la parte final del siglo convivieron un código penal concienciado por los problemas derivados de los ataques a la reputación personal con una legislación de prensa bastante liberal, de lo que surgieron no pocos conflictos.

\section{EL HONOR DE LOS PARTICULARES}

\section{1. El honor de los varones}

La asociación entre respetabilidad, reputación profesional e imagen pública constituía la base de la relación del varón burgués con su entorno social. Establecía su lugar en el mundo, fijaba su posición social y consolidaba su situación hegemónica en la jerarquía familiar. Sin embargo, la sensación de ansiedad ante las amenazas a su honor era algo que permeó la mentalidad masculina durante todo el siglo XIX y, al menos, la primera década del siglo siguiente ${ }^{22}$. Frente a la estabilidad del linaje que, apoyado en el apellido familiar,

20 Para el cotejo de los distintos artículos y los comentarios de los especialistas, véase: Código penal reformado por ley de 17 de junio de 1870 que autoriza su planteamiento provisional comparado con el de 30 de junio de 1850 y comentado en algunos puntos por don Celestino Mas y Abad, abogado de los tribunales, Imprenta y Estereotipia de M. Rivadeneyra, Madrid, 1870. E1 Código de 1870 nació como una actualización provisional del de 1848/1850 en espera de que las Cortes discutieran uno definitivo, adecuado a la nueva constitución de 1869. Sin embargo, se mantuvo vigente hasta 1928, en que la dictadura impuso su propio código. Volvió a entrar en vigor al ser proclamada la Segunda República y hasta 1932, cuando se aprobó el código penal del nuevo régimen.

21 Artículos 14, 15 y 16, Gaceta de Madrid, 30 de julio de 1883.

22 François Guillet, "La tyrannie de l'honneur. Les usages du duel dans la France du premier XIXe siècle”, Revue historique, n 640, 2006/4, pp. 892-893. 
la estructuración estamental de la sociedad y las propiedades vinculadas, daba una cierta solidez al individuo, en el mundo burgués el sujeto se hallaba expuesto a desafios continuos. Desafios que había de afrontar (salvo en casos específicos) de manera solitaria. Por otra parte, el proceso de complejización de la administración del Estado fue acompañado de un amplio proceso jurídico que, como ya hemos visto, se introdujo también en el ámbito de la protección del honor. Sin embargo, para muchos contemporáneos, y en especial, para todos los tratadistas del llamado "código del honor", el Estado no debía traspasar determinadas fronteras que correspondian a la intimidad del individuo y constituían un espacio privativo que solo a él le correspondía proteger. Para ello, no había otro camino que una forma alternativa de justicia al margen de las leyes: el duelo ${ }^{23}$.

Los tribunales no siempre admitieron las demandas resultado de insultos o altercados entre individuos que hubieran tenido alguna pendencia en la calle o en cualquier otro espacio, público o privado. Eso era algo incontrolable y que formaba parte de la vida cotidiana de las personas. Además, y como establecieron los códigos penales para este tipo de delitos contra el honor, salvo para casos específicos que veremos después, el procedimiento solo se iniciaba tras la demanda presentada por la parte ofendida, es decir, no se actuaba de oficio. Una vez que se había puesto en marcha la justicia, las razones por las cuales se habia producido la ofensa saldrían a la luz pública, de ahí la reticencia de muchos varones a seguir el camino previsto por la ley y su opción por la expeditiva vía del desafio. En palabras del famoso maestro de esgrima Adelardo Sanz: “...hay asuntos en que los tribunales resultan impotentes, por su indole especial y por ser en su mayor número imposibles de probar"24.

En las denuncias examinadas para la realización de este trabajo hay una reiteración del agravante de publicidad, es decir, que las ofensas se hubieran producido en espacios públicos. Si bien en lugares privados el ofendido podía exigir una retractación, ignorar los hechos o retar al ofensor, cuando había más personas presentes, el ataque tomaba otra dimensión. Además de las palabras, especialmente ofensivos resultaban gestos como pegar al otro o escupirlo. Es bien cierto que, en algunos casos, y sobre todo si había habido reciprocidad en el ejercicio de la violencia, los tribunales solian desestimar las denuncias o condenar a ambos contendientes. Sin embargo, en el caso de que, por ejemplo, un individuo escupiera a otro en público, lo que a menudo sucedía después de proferir palabras ofensivas, se consideraba injuria grave "dada la significación que esto tiene entre las personas de honor", como dejó escrito el jurista Hidalgo García. Las sentencias nos muestran con claridad que por "personas de honor" se entendia a personas de cierto nivel social, pues el hecho de escupir a otro "en la

23 Ute Frevert, Men of Honor. A Social and Cultural History of the Duel, Wiley, Londres, 2007 (1995), pp. 138-139. El “código del honor" era el conjunto de reglas no escritas que todo varón (y toda mujer) conocia en tanto que formaban parte de su educación informal desde la infancia. Estas reglas no escritas se reforzaban especialmente en los espacios de homosociabilidad, como los casinos o los cuarteles. Pese a todo, se publicaron en Europa varios tratados que trataron de sistematizar ese código. Uno de los más famosos fue el del conde de Chateauvillard, traducido al español por el periodista Andrés Borrego. El más conocido de los publicados en español fue el del marqués de Cabriñana, con el expresivo título de Lances entre caballeros (1900).

${ }^{24}$ Adelardo Sanz, Esgrima del sable y consideraciones sobre el duelo, Imprenta de Fortanet, Madrid, 1886, p. 152. 
cara y sombrero" nos está hablando de que es la indumentaria la que nos define la categoría social del individuo ofendido. El sombrero nos remite a varones de la burguesia y la aristocracia, entre los que esas prácticas, consideradas vulgares en grado extremo, resultaban especialmente ofensivas, de ahí la gravedad con la que se entendia en ese contexto ser el individuo ofendido. Escupir a alguien se consideraba algo propio de clases populares. Si tal circunstancia se producía entre personas de otro nivel social, en el que se suponia que tales conductas estaban ausentes, se mostraba expresamente el grado de minusvaloración en el que el ofensor tenía al ofendido. De ahí que la reparación fuera tan necesaria. En el caso de las sentencias consultadas, el veredicto se ajustaba al supuesto tercero del artículo 472 del código de 1870: "las injurias que por su naturaleza, ocasión o circunstancias fueren tenidas en el concepto público por afrentosas" 25.

El hecho de que las acusaciones se hicieran en público también era una circunstancia agravante en el delito de calumnia, como muestra un interesante caso sucedido en una iglesia. Aunque la fuente no indica la localidad, sí podemos saber que los hechos tuvieron lugar entre finales de la década de 1870 y los inicios de la de 1880. En la celebración de una misa y delante de todos sus feligreses, un sacerdote acusó a un padre y un hijo de la localidad de haber presentado testigos falsos en un pleito para recibir una herencia que, según él, no les correspondia y que, por lo tanto, habian adquirido ilicitamente. Dijo, incluso, que ambos eran "lazos de Lucifer", conminando a "los fieles presentes [a] que no compraran ni arrendaran los bienes de la herencia que habian aquellos adquirido". El falso testimonio en un juicio, del que acusaba el cura a sus dos feligreses, era un delito contemplado en el código penal que se debía perseguir de oficio, por lo que se le exigieron pruebas de tal delito. Como el sacerdote no pudo aportar ninguna prueba de los hechos de los que acusaba a los demandantes, la sala de la audiencia que atendió el caso dio la razón a estos últimos ${ }^{26}$. Resulta llamativo, sin embargo, que la sentencia no contemplara como agravantes el hecho de que el sacerdote se prevaliera de su condición de autoridad espiritual de la comunidad de fieles a la que estaba predicando y de que la calumnia se produjera durante la realización de una ceremonia religiosa.

En todo caso, lo que nos muestran estos casos de delitos de calumnias e injurias en los que los insultos tuvieron lugar en espacios públicos, es que el honor se definía en relación a los otros. Eran los otros los que reconocian el honor personal, por lo tanto, se convertía en una necesidad imperiosa el luchar por la propia reputación pues esta era tal en tanto que todos la reconocian y dejaba de serlo si el individuo no se ocupaba de lavar su imagen. Se trataba de la "responsabilidad moral que impone la opinión pública", como dejó escrito el jurista y miembro de la comisión codificadora del Código de 1848 Cirilo Álvarez Martínez ${ }^{27}$. O, en una expresión muy común a lo largo del siglo XIX, la "tiranía de

\footnotetext{
25 Señalemos como ejemplo la sentencia de 28 de octubre de 1872 (Gaceta de Madrid, 20 de noviembre de 1872) y las de 9 de abril de 1900, 27 de febrero de 1901 o 8 de junio de 1901 (Juan Antonio Hidalgo García, El Código Penal, op. cit., p. 436). Por razones fáciles de entender, los comentarios de las sentencias apoyadas en el Código penal de 1870 y las sentencias aparecidas en la Gaceta no suelen incluir, en general, los nombres de los afectados.

26 Sentencia de 28 de septiembre de 1881 (Juan Antonio Hidalgo García, El Código Penal, op. cit., p. 368).

27 Cirilo Álvarez Martínez, Ensayo histórico-filosófico-legal sobre el duelo, La Ilustración, Madrid, 1847, p. 67. Álvarez Martínez formó parte también de la comisión codificadora creada por el
} 
la opinión". En última instancia, la clave no era la veracidad de la acusación que se vertía sobre alguien, sino que se hubiera producido dicha acusación. La razón no importaba, es más, la razón ni siquiera debía salir a la luz ${ }^{28}$. De ahí que hubiera que conjurar, también públicamente, el agravio a través de una representación exterior en forma de juicio o, en el peor de los casos, en forma de desafio.

\section{2. El honor de los profesionales y las empresas}

Un capitulo especialmente interesante es el de los ataques al honor de los profesionales. Como se dijo con anterioridad, la reputación constituía el depósito no solo del honor personal, sino también del valor que respaldaba la respetabilidad de todo profesional liberal. Era su crédito ante sus potenciales clientes y ante sus pares. Cualquier sospecha acerca del ejercicio de su profesión o de su moralidad pública podia constituir un baldón muy dificilmente superable. Esa es la razón por la que encontramos en la jurisprudencia demandas de profesionales liberales de toda condición hacia acusaciones contra su honor personal y/o profesional, en tanto que ambos eran claramente intercambiables. Muchas de estas sentencias presentan como ofensores a articulistas de prensa. Se trata de los casos más evidentes de conflicto entre lo que los periodistas entendian como libertad de expresión y lo que, con terminología actual, llamaríamos derecho a la información ${ }^{29}$. Un ejemplo lo podemos encontrar en la demanda interpuesta por un abogado contra un periodista que planteaba dudas ante la competencia profesional y el estado mental del primero. Tras diversas circunstancias, el Tribunal Supremo falló a favor del abogado. Las palabras del comentarista de la sentencia son claramente ilustrativas de lo que aquí se está diciendo: "...tales frases conscientemente empleadas revelan manifiesta tendencia de menospreciar y se encaminan al descrédito de la persona ofendida, por atribuirle caprichosamente un estado intelectual que siendo incierto afecta a la reputación del hombre en sus relaciones sociales y al natural respeto en ellas exigido" 30 . Un sector especialmente vulnerable a este tipo de acusaciones contra

gobierno provisional a mediados de agosto de 1843 con el objeto de modificar el Código penal de 1822.

28 Sobre esta cuestión, escribía el también jurista Alejandro Groizard lo siguiente: "A la ley basta con que el honor resulte atacado sin otro fin que el animus iniuriandi, para apreciar el delito, sin necesidad de conocer si es cierto o es falso el hecho, el vicio o la falta de moralidad que se atribuye al ofendido. La prueba, por punto general, en el delito de injuria debe ser rechazada, porque no conduce a ningún resultado influyente en los elementos esenciales del delito y porque en la mayor parte de los casos da ocasión a nuevos agravios contra el honor, estériles para los fines de la justicia”, Alejandro Groizard y Gómez de la Serna, Código Penal de 1870 concordado y comentado, op. cit., p. 366.

29 Los periodistas, en general, protagonizaron una parte importante de las demandas por calumnias e injurias. La mayor parte de ellas tuvieron que ver con razones de tipo politico. Sobre estas cuestiones: Juan Carlos Mateos Fernández, "Cuestión de honor. Los periodistas se baten en duelo", Historia y comunicación social, $\mathrm{n}^{\circ}$ 3, 1998, pp. 323-342; y Raquel Sánchez, "Honor de periodistas. Libertad de prensa y reputación pública en la España liberal", en Raquel Sánchez y José Antonio Guilllén Berrendero (eds.), La cultura de la espada. De honor, duelos y otros lances, Dykinson, Madrid, 2019, pp. 305-332.

30 Sentencia de 19 de mayo de 1884 (Juan Antonio Hidalgo García, El Código Penal, op. cit., p. 395). 
la honorabilidad profesional fue el de los médicos. Dada la naturaleza de su profesión, la posibilidad de que sus diagnósticos o sus tratamientos fracasaran constituía un elemento que convertía el ejercicio de la medicina en un foco de conflictos. Son varias las sentencias que asi lo prueban. En unos casos, las acusaciones se produjeron verbalmente, como aquella en la que un médico demandó por injurias graves a una mujer cuyo hijo había muerto por un error en el diagnóstico. Ante el problema de hidropesía del niño, el médico había diagnosticado tuberculosis, obligando a la familia a unos gastos económicos considerables al recomendar un viaje a Panticosa para el restablecimiento del enfermo. La madre increpó duramente al facultativo por el fallecimiento del niño y aquel denunció a la mujer. El tribunal no consideró que se tratara de injurias graves, sino leves, porque sus palabras "no revelan el propósito de injuriar y perjudicar considerablemente la fama y crédito del agraviado, sino sólo el de censurarle por la fatal terminación de la enfermedad del hijo"31. En otros casos, y si las palabras se proferían con publicidad y por escrito, el veredicto era más duro. Un padre publicó en la prensa una carta acusando de negligencia al médico que había atendido a su hijo fallecido. Tras el procedimiento judicial, que terminó con un recurso de casación en el Tribunal Supremo, este declaró que la acusación de negligencia "redunda en su descrédito [del médico] y menosprecio constituyendo por su naturaleza, ocasión y circunstancias el delito de injurias graves"32.

Aparte de los profesionales liberales, otro colectivo especialmente sensible a las difamaciones fue el de los empresarios o dueños de negocios, que también tenían en la confianza pública su principal capital. En un mercado progresivamente más competitivo, mantener la estimación de los consumidores era algo de primera importancia. De ahí que las acusaciones que se pudieran verter contra la calidad de los productos y servicios ofrecidos y contra la honestidad de los propietarios de tales negocios constituyera el núcleo de las reclamaciones. También en este caso vemos la importancia de la prensa como elemento propagador de rumores y noticias que, verdaderas $\mathrm{o}$ falsas, constitutivas de delito o no, dejaban su huella en la mente de los potenciales clientes. Disponemos de un caso curioso en el que se mezclan los comentarios de un periodista con el deterioro de la imagen pública de un fabricante. En un artículo de prensa, un periodista escribió que desde que sus hijos habían cambiado de desayuno, se hallaban bastante mejor que antes, dando a entender que cuando tomaban los chocolates fabricados por el empresario en cuestión su salud se había deteriorado. El fabricante demandó al periodista por calumnias, pero la audiencia no vio indicios de delito, por lo que el fabricante apeló al Tribunal Supremo. Este tribunal resolvió que no se podía acusar al periodista de calumniador, pues solo había propalado la sospecha de que el fabricante vendía chocolates adulterados, pero no le había imputado la comisión del delito como tal. Sin embargo, el Tribunal sí condenó al articulista por injurias graves, al ver en su artículo una evidente intención de atacar el crédito público del fabricante "porque nada es susceptible de ocasionar tan profundo deshonor ni mayor descrédito a quien ejerce la industria de fabricante o comerciante, ni es capaz de

\footnotetext{
${ }^{31}$ Sentencia de 7 de enero de 1899 (Juan Antonio Hidalgo García, El Código Penal, op. cit., p. 408).

32 Sentencia de 21 de octubre de 1892 (Juan Antonio Hidalgo García, El Código Penal, op. cit., p. 435).
} 
hacérselo sentir tan vivamente delante de las gentes, como el que se le presente a los ojos del público con la nota de sospechoso de falsificar los productos que elabora o expende y de corresponder con el engaño a los que a él acuden llenos de confianza"33. La frontera entre ambos delitos era, en casos como este, muy frágil, sobre todo teniendo en cuenta el daño que, en los intereses de cualquier fabricante, podia causar un rumor acerca de la calidad de sus productos. La importancia creciente de la colisión entre la libertad de prensa y el derecho al honor de productores y firmas comerciales se plasmó en la extensión de protección en materia de honor y reputación a las empresas, como poseedoras de personalidad jurídica y en tanto que eran la expresión de los actos de los individuos que las componían ${ }^{34}$.

\subsection{El honor de las mujeres}

Como se dijo en páginas anteriores, el honor de las mujeres era algo que competía directamente a los varones bajo cuya protección se hallaban. Eso no era óbice para que en la jurisprudencia puedan encontrarse un número significativo de mujeres que, ante los ataques a su honor, recurrieran a la justicia para tratar de lavar su reputación. Además, las mujeres tenían cerrado el acceso al camino alternativo utilizado por los varones para limpiar las manchas en su honor: el duelo. En las sentencias consultadas, las ofensas, en forma de calumnia o de injuria, provenian tanto de hombres como de mujeres, aunque es llamativo el relativamente alto número de demandas entre mujeres, por disputas entre ellas sobre cuestiones relacionadas con su estimación como "señoras", en el sentido que esta palabra tenía en el contexto que nos ocupa. En el discurso de la domesticidad burguesa vigente en el siglo XIX, el principal capital de una mujer residia en su reputación como mujer honrada. De ahí que su conducta en materia sexual se convirtiera en el centro de una ansiedad generalizada por proteger su imagen y la de sus hijos, en tanto que descendientes legítimos del padre de familia. Como es sabido, una de las grandes preocupaciones que, en relación al comportamiento femenino, obsesionó en el siglo XIX fue el adulterio, como tan frecuentemente reflejó la literatura de la época.

Por tanto, el insulto de "puta" dirigido a una mujer era considerado una injuria grave, como muestra, por ejemplo, la sentencia de 22 de noviembre de $1873^{35}$. Esta sentencia se apoyaba en el punto segundo del artículo 472 que establecia que una injuria grave se producia cuando el ofensor proferia palabras que acusaban de "un vicio o falta de moralidad, cuyas consecuencias pueden perjudicar considerablemente la fama, el crédito o el interés del agraviado". En este caso en particular, con el agravante de que la acusación se produjo en un lugar público. En la misma línea se pronunciaban los jueces si la calumnia o la injuria indicaba que la ofendida se dedicaba a actividades de mediadora en las

33 Sentencia de 15 de junio de 1883 (Juan Antonio Hidalgo García, El Código Penal, op. cit., p. 394).

${ }^{34}$ Sentencia de 21 de abril de 1890 (Juan Antonio Hidalgo García, El Código Penal, op. cit., p. 403).

35 Salvador Viada y Vilaseca, Código penal reformado de 1870, op. cit., p. 614 (Viada remite erróneamente a la Gaceta de Madrid del 19 de febrero de 1874). 
relaciones sexuales de otros al ser acusada, por ejemplo, de "alcahueta" 36 . Los insultos contra la moral sexual tenian una importancia superior a las acusaciones relacionadas con otro tipo de delitos que también podian afectar a la reputación pero que, sin embargo, eran considerados de menor entidad ante el mal mayor causado a su imagen pública como mujeres virtuosas. En la sentencia que comentaremos a continuación, resulta evidente cómo la acusación de robo a una mujer tuvo infinitamente menos peso que la recriminación hecha por la otra parte de una falta relacionada con su moralidad. Se trata de un caso surgido entre dos mujeres al acusar una de ellas a la otra de "ladrona y pilla". La segunda respondió diciendo a su contrincante "que era una..., que habla estado... la noche del Jueves Santo con unos señores en la Alameda". Dado que la acusada de prostituta era una mujer casada, la respuesta del Tribunal Supremo al recurso de casación interpuesto por la ofensora explicaba que, por una parte, se trataba de la imputación de falta de moralidad y, por otra, de un delito privado que afectaba directamente a la reputación de la mujer ofendida. No se tuvo en cuenta como atenuante el hecho que la discusión se entablara en el acaloramiento de una disputa (lo que sí había considerado el tribunal ordinario que juzgó el caso en primera instancia) sino que, precisamente por la condición de mujer casada de la ofendida, la gravedad de los insultos y la imposibilidad de revertirlos, pues ya habian manchado su fama, había que considerar que se habian proferido con toda la intención de ensuciar su imagen pública. La firmeza de la decisión del Tribunal Supremo y su insistencia en la condición de mujer casada de la querellante nos indica la existencia de un claro interés por proteger al núcleo familiar de las acusaciones de desviación de la moral sexual imperante. Un caso similar son las acusaciones vertidas sobre una mujer de haber padecido sífilis, con las implicaciones que de ello podian derivarse ${ }^{37}$. En el contexto en el que nos estamos moviendo, los insultos de la parte ofensora no iban dirigidos solamente hacia la esposa, sino que repercutian directamente en su marido e indirectamente en los hijos del matrimonio. Si bien el tribunal solo juzgaba los hechos producidos en un momento concreto, la mancha en la reputación levantaba una sospecha sobre el resto de la vida de la mujer ofendida, sobre la reputación del marido y sobre la legitimidad de los hijos habidos en el matrimonio ${ }^{38}$. Precisamente las acusaciones de presunta ilegitimidad de los hijos constituian un caso de injurias graves, dada la imposibilidad de probar los hechos y el daño que se causaba con tales imputaciones ${ }^{39}$. El ya citado jurista

36 Salvador Viada y Vilaseca, Código penal reformado de 1870, op. cit., p. 614. Otro ejemplo en la sentencia de 17 de diciembre de 1872 (Gaceta de Madrid, 14 de febrero de 1873). Curiosamente, en una sentencia de 10 de enero de 1898 en respuesta al recurso de casación de una de las querellantes, el Tribunal Supremo desestimó la demanda de injurias de esta. La razón que se arguyó fue que, al haber proferido las dos partes palabras en el mismo sentido ("puta y zorra"), los insultos se habían producido en el contexto de una discusión, que se trataba de una "interjección accidental en la misma riña" y que se habian dicho "para rechazar iguales ofensas" (Juan Antonio Hidalgo García, El Código Penal, op. cit., p. 416).

37 Las acusaciones referian a una mujer a la que se calificaba de "bribona" que "ha curado en otro tiempo gálico bajo las paneras [los hórreos]" (sentencia de 6 de febrero de 1871, Gaceta de Madrid, 26 de marzo del mismo año).

38 Sentencia de 11 de marzo de 1895 (Juan Antonio Hidalgo García, El Código Penal, op. cit., p. 412).

39 Sentencia de 12 de enero de 1898 (Juan Antonio Hidalgo García, El Código Penal, op. cit., p. 416-417). El caso al que se refiere esta sentencia es especialmente interesante porque la acusación de ilegitimidad se produjo al dia siguiente de una discusión entre dos mujeres que, 
Alejandro Groizard lo explicaba muy claramente: "Las investigaciones y pesquisas en el santuario del hogar, acerca de acciones relacionadas con la vida moral del hombre, no deben permitirse sino en casos excepciones, puesto que la mayor parte de las veces serian de más entidad los daños sociales que resultarian de emplear aquellos medios para descubrir secretos de familia o verificar vicios $\mathrm{y}$ faltas morales de sus individuos" 40 .

Las ofensas contra el honor no solo afectaban a las mujeres casadas. La conducta intachable de una joven casadera constituía la base para aspirar a un buen matrimonio. Siendo la belleza, el dinero y una buena posición social elementos de primera importancia para concertar un ventajoso enlace, sin una reputación absolutamente limpia ninguna joven podía plantearse pasar por la vicaria en condiciones óptimas. Es por eso que las demandas planteadas a este respecto incidieron en tales aspectos de forma reiterada. En una sentencia de 26 de octubre de 1872 se condenaba a una mujer que acusó a una "joven soltera de intachable reputación" con palabras con las que claramente se aludia a un presunto embarazo ("calla tú, bribona, que todavia no me ha pegado mi madre por tapar esta [la barriga]"). Ello, como decía el comentarista jurídico Viada refiriéndose a la joven insultada, podia "comprometer de modo trascendente su porvenir"41. La susceptibilidad que despertaban las potenciales acusaciones contra el honor femenino debía ser enorme, como muestra el siguiente ejemplo. En una celebración nocturna de Carnaval en la década final del siglo, una mujer tapada con una máscara se acercó a una joven a la que dijo que sabía que se había escapado con un hombre, cuyo nombre mencionó. La joven denunció los hechos, resultando culpable de injurias graves la ofensora, quien puso un recurso de casación ante el Tribunal Supremo alegando que no pretendia ofender, que tales palabras habian sido dichas en un contexto lúdico y que tan solo eran una broma. El Tribunal Supremo desestimó el recurso con dos argumentos que ilustran claramente la normatividad moral imperante, como nos cuenta el comentarista jurídico Juan Antonio Hidalgo. Por una parte, y reconociendo que en la época de Carnaval podian permitirse "ciertas libertades en el decir", consideraba que la ofensora se había prevalido de su máscara para insultar a la parte ofendida, rebasando la linea de unas diversiones "lícitas cuando no traspasen las fronteras de la legalidad, se infrinjan preceptos legales y se lastime impunemente, por alguno de los modos que proveen, la honra, el crédito y la dignidad de las personas, que en todo tiempo protege y ampara el legislador". Por otra parte, y aquí se incide claramente en la condición de la joven soltera cuyo patrimonio principal es su honra, señala que "el imputar a una hija de familia la fuga de su domicilio, con un hombre, no puede dejar de ser gravemente injurioso"42.

además, eran hermanas. El tribunal consideró que no había lugar a atenuante alguno porque la imputación de falta de moralidad se habia produjo muchas horas después del altercado.

40 Alejandro Groizard y Gómez de la Serna, Código Penal de 1870 concordado y comentado, op. cit., p. 366.

41 Sentencia de 26 de octubre de 1872, publicada en la Gaceta de Madrid el 9 de diciembre del mismo año. Los comentarios de Viada en Código penal reformado de 1870, op. cit., p. 613.

42 Juan Antonio Hidalgo García, El Código penal, op. cit., pp. 417-418. 


\section{EL HONOR DE LAS AUTORIDADES}

Como hemos visto hasta ahora, los delitos contra el honor se consideraban delitos de carácter privado, es decir, correspondía al ofendido demandar al ofensor, perdonarlo o aceptar su retractación. Sin embargo, la evolución de la codificación y el reforzamiento del poder social del Estado condujeron a que las potenciales calumnias, injurias e insultos de todo tipo que se hicieran sobre personas o instituciones que representaran el poder público fueran considerados delitos de otra categoría. Se trata del nacimiento del delito de desacato, que fue incluido en 1850 cuando tuvo lugar la reforma del Código penal de 1848. En la decisión de incluir el delito de desacato tuvieron un peso importantísimo el desarrollo de la prensa escrita desde 1833 y la experiencia de la reciente revolución de $1848^{43}$. En España, al igual que en otros países (y aunque los resultados de esta experiencia fueron distintos según el contexto del que estemos hablando) se amortiguó el sonido de la revolución por la vía de la represión puesta en marcha por el general Narváez, lo que no quiere decir que se acallaran las voces discrepantes. El aprendizaje que se obtuvo de todo ello hizo girar al gobierno hacia posiciones más conservadoras y, en algunos casos, reaccionarias. Esto es claramente perceptible en la reforma del Código que se llevó a cabo en 1850, una reforma que se caracterizó sobre todo por el endurecimiento de las penas y el control de los delitos políticos. Lo mismo puede decirse, como ya se ha visto, de la legislación sobre libertad de imprenta. Con esta reforma, el desacato fue considerado un delito público, por lo que podía ser perseguido de oficio. Se justificaba porque los intereses afectados por las injurias y calumnias a las autoridades eran, en cierto modo, superiores a los intereses de los particulares ${ }^{44}$. Los insultos repercutian en las instituciones del Estado, que merecían una protección especial, de carácter ejemplarizante. El delito de desacato se mantuvo en el Código de 1870, con las mismas especificaciones acerca de que se consideraría desacato cuando las agresiones de obra o de palabra se produjeran sobre la persona que encarnaba la autoridad en el ejercicio de sus funciones.

No es cuestión de extenderse aquí en la enumeración de las distintas formas que podía adoptar el delito de desacato en función de las circunstancias en las que se producía. Sin embargo, sí reviste interés la delgada línea que separaba la consideración de una crítica a un ministro (por poner un ejemplo) como delito de desacato con una limitación a la libertad de prensa. En sus comentarios al Código de 1870 Salvador Viada apuntaba que la publicación por la prensa periódica de escritos contra ministros $u$ otras autoridades no podía ser considerada desacato ya que el escrito debía estar dirigido a estas autoridades en persona ${ }^{45}$. Lo cierto es que, en última instancia, correspondía al juez dirimir si tales palabras eran ofensivas para la autoridad o no, con lo que se abría la puerta

43 Se puede encontrar un repaso detallado de las razones que llevaron a la comisión de codificación a incluir este nuevo delito en los comentarios a la reforma de 1850 que publicaron José Castro Orozco (marqués de Gerona) y Manuel Ortiz de Zúñiga en su libro Código Penal reformado, con el texto ajustado a la nueva edición oficial y con anotaciones y observaciones sobre las reformas y sus motivos, Imprenta de Santiago Saunaque, Madrid, 1850, pp. 33 a 46. Los autores plantean también en este trabajo sus reticencias hacia ciertos aspectos de la nueva regulación.

44 Alejandro de Pablo Serrano, Los delitos contra el honor en el derecho penal español y en el derecho comparado, op. cit., p. 209.

45 Salvador Viada y Vilaseca, Código penal reformado de 1870, op. cit., p. 320. 
a interpretaciones particulares claramente ideológicas. En todo caso, dejaremos de lado estos casos relacionados con la prensa política pues para los objetivos que se persiguen en este artículo es más productivo analizar cómo se plasmó la protección del honor de las personas que representaban al Estado en un nivel más próximo a la vida diaria de la España de la época.

En la vida cotidiana de los españoles del siglo XIX, como en el resto de épocas históricas, las criticas a las autoridades formaban parte de la manifestación pública de rechazo hacia decisiones o comportamientos considerados arbitrarios por parte de los poderes públicos y las fuerzas del orden. En ocasiones, tales discrepancias acababan en protestas de mayor o menor envergadura. Sin embargo, en la mayoría de los casos, se trataba de desahogos individuales o colectivos que desaparecian en breve tiempo. En las pequeñas poblaciones, además, los cargos de alcalde, secretario de ayuntamiento, etc., solian estar desempeñados por individuos de esta misma localidad. Es decir, se trataba de personas conocidas por todos y a los que se trataba no tanto como a "la autoridad" sino como a un vecino más, por lo que las extralimitaciones verbales se producian en contextos de relativa familiaridad, profiriendo palabras y expresiones que, si bien técnicamente eran ataques a la autoridad, no tenían el contenido político que podemos encontrar en las criticas a las autoridades que se vertian en la prensa nacional. Si examinamos algunas de las sentencias sobre desacato publicadas en los años setenta, lo veremos con claridad. En el municipio de Navaluenga (provincia de Ávila) el alcalde se hallaba ayudando al recaudador de contribuciones cuando un vecino le increpó acusándole de "ladrón, que estaba robando al pueblo". Tras un primer fallo de los tribunales ordinarios, el caso terminó en el Tribunal Supremo, que respaldó el fallo inicial de desacato contra el vecino que insultó al alcalde, pues, aunque probara que eran ciertas sus acusaciones, no tenía ningún derecho a injuriar a la autoridad ${ }^{46}$. En definitiva, el alcalde podía estar cometiendo un delito de robo, que habría de ser perseguido por otras vías, pero que el acusador demostrara la certeza de tal robo, no le eximía a él del delito de desacato. El reforzamiento del peso social del poder público queda claramente de manifiesto con sentencias como esta. Una situación similar se planteó cuando en 1873 el comisionado de apremio para el pago de atrasos de ciertas contribuciones se presentó ante el contribuyente al que se demandaban dichos atrasos. Este reaccionó con gran violencia verbal llamándole "ladrón y farsante", por lo que fue condenado por delito de desacato al haber proferido injurias graves sobre la persona de un funcionario público ${ }^{47}$. Otra era la situación que se planteaba cuando las ofensas a la autoridad se producían en ausencia de estas y con determinadas circunstancias atenuantes. Ese es el caso de un maestro de enseñanza primaria de un pueblo que, en estado de embriaguez y en público, acusó al alcalde y al secretario del ayuntamiento de robar la partida consignada para su salario. Acusado de desacato a la autoridad por el alcalde y el secretario, el maestro recurrió la sentencia fallada en primera instancia y el Tribunal Supremo, finalmente, le dio la razón, negando que pudiera ser acusado de desacato al no hallarse físicamente presentes dichas autoridades cuando se

46 Sentencia de 1 de febrero de 1872 (Gaceta de Madrid, 16 de abril del mismo año).

47 Sentencia de 19 de mayo de 1874 (Salvador Viada y Vilaseca, Código penal reformado de 1870, op. cit., p. 325). 
produjeron los insultos ${ }^{48}$. Los temas más socialmente sensibles, los relacionados con las contribuciones y, en general, con asuntos de dinero, constituyen la mayor parte de las acusaciones que se hicieron a las autoridades tanto locales como nacionales, a tenor de las sentencias aparecidas en la Gaceta de Madrid, y en las recogidas por Viada y por Hidalgo.

\section{EL DUELO COMO ALTERNATIVA}

Un capítulo aparte en lo que se viene aquí considerando lo constituye el duelo, regido por un código del honor vigente entre las élites masculinas y al que el Estado trató de poner coto, a pesar de que, como dijo un jurista contemporáneo, aquellos que tenían que legislar sobre él eran los primeros en practicarlo ${ }^{49}$. Según los principios del código de honor, un caballero no podía aceptar una satisfacción material por la ofensa recibida en forma de arresto de su ofensor, y mucho menos una compensación económica. Eso era algo impropio de un varón que se respetase a sí mismo y una ofensa a su dignidad. A pesar de los deseos de los juristas de que no salieran a la luz los asuntos privados, la regulación de este tipo de delitos por parte del Estado era considerada por los "hombres honorables" como una extensión de las funciones de aquel, que se introducía en la vida más íntima de los individuos. Por tanto, los ataques al honor eran contemplados por los hombres honorables como algo que se "sentía", una percepción imposible de ser contemplada por algo tan externo al sentimiento como la ley. No podía, por tanto, positivizarse en los códigos penales pues, en última instancia, eran sucesos excepcionales en la convivencia de unas elites regidas por los mismos valores. No existía más código para lavar estas afrentas que el código del honor, cuyo ejercicio no podía ser puesto en marcha por agentes externos al afectado: ni el Estado, ni la policía ni los jueces podian actuar de parte del agredido. Era algo tan sumamente privado que ni siquiera la Iglesia podia intervenir en ello. La Iglesia, de hecho, contemplaba este código del honor y su práctica de forma muy negativa. El derecho canónico era, a este respecto, mucho más exigente que el penal. Desde la perspectiva de la Iglesia católica, el duelista solo podia ser considerado desde dos perspectivas: o era un suicida o era un asesino. En ambos casos, el individuo cometía pecado mortal ${ }^{50}$.

Por supuesto, la legislación penal condenó la práctica del duelo dedicándole atención a las diversas situaciones en que se podía producir. Si bien la Novísima Recopilación consideraba el duelo un delito infame que castigaba con la pena de

48 Sentencia de 1 de febrero de 1872 (Salvador Viada y Vilaseca, Código penal reformado de 1870, op. cit., pp. 325-326).

49 Cirilo Álvarez Martínez, Ensayo histórico-filosófico-legal sobre el duelo, op. cit., p. 8.

50 Miguel Martorell, "Un duelo en 1900: Un 'delito especial”, en Javier Alvarado Planas, Miguel Martorell (coords.), Historia del delito y del castigo en la Edad Contemporánea, UNED/Dykinson, Madrid, 2017, pp. 372-373. Sobre los procedimientos y rituales del duelo, además de los códigos de honor de la época, puede consultarse: Jordi Luengo López, "Masculinidad reglada en los lances de honor: desafios burgueses en el cénit de un fin de época (1870-1910)", Rúbrica contemporánea, vol. $7, \mathrm{n}^{\circ} 13,2018$, pp. 59-79. La mentalidad que justificaba la práctica del duelo en Raquel Sánchez: " 'El duelo es una necesidad de los tiempos presentes'. Opiniones sobre el carácter civilizador del duelo en la España del siglo XIX", Memoria y Civilización, n 23, 2020, pp. 1-21. 
muerte ${ }^{51}$, no hay referencias al mismo en el código penal de 1822. Sí se aborda, y con cierto detenimiento, en los códigos de 1848/1850 y 1870. De hecho, este último reproduce la legislación anterior salvo en lo referente al importe económico de las multas, que se actualizan a la nueva moneda: la peseta. El código de 1848/1850 dedica al duelo el capítulo VI del título noveno ("Delitos contra las personas") en sus artículos 349-357. En el código de 1870 el duelo se trata en capítulo IX del título octavo ("Delitos contra las personas"), artículos 439-44752. En ambos códigos la pena de muerte para los duelistas que decretaba la Novisima Recopilación ha desaparecido, imponiéndose la pena de prisión mayor para los casos más graves, o sea, desobediencia a la autoridad cuando esta haya tenido conocimiento del desafio y haya advertido a los rivales acerca de la ilegalidad del acto y cuando se haya matado al contrincante pues el duelo, en última instancia, no dejaba de ser un homicidio o, según cómo se considerase, un asesinato. Muy interesantes son los artículos 354 (código de 1848/1850) y 444 (código de 1870) porque están directamente relacionados con la publicidad de los ataques al honor: "El que denostare o desacreditare públicamente a otro por haber rehusado un duelo, incurrirá en las penas señaladas para las injurias graves". El legislador trataba, de esta forma, de revertir un prejuicio ampliamente arraigado entre las elites masculinas. De este modo, se trataba de estigmatizar una práctica ampliamente difundida a través de su positivización como un delito, dentro del espíritu que, en países como el Reino Unido, había logrado deslegitimar el duelo como medio para solventar conflictos entre los individuos ${ }^{53}$. La alternativa planteada por muchos contemporáneos era la creación de tribunales de honor de carácter corporativo que permitieran solventar dichos conflictos. El modelo fueron los tribunales de honor castrenses, que habian sido creados por real decreto de 3 de enero de 1867 y que se consolidaron en el Código de Justicia Militar de $1890^{54}$. Sin embargo, y a pesar los repetidos intentos, tales proyectos no obtuvieron el éxito deseado.

Como consecuencia de ello, la práctica del duelo continuó e incluso se agravó, con casos muy famosos como el duelo entre el marqués de Pickman y el capitán Vicente Paredes ${ }^{55}$. Resultaba evidente para la opinión pública que apenas se aplicaba el código penal en este tipo de delitos por la condición social de los implicados, por lo que la impunidad de los duelistas era casi total. La cuestión llegó a saltar a los escaños del Congreso cuando en febrero de 1902 Ramón Nocedal pidió el fin de esta situación, siendo apoyado por otros diputados como Sagasta, Azcárate, Barrio y Mier, Navarro Reverter y Romero Robledo56. Las loables intenciones de

51 Novísima Recopilación de las leyes de España, [s.i.], Madrid, 1807, tomo V, libro XII, título 20 (“De los duelos y desafíos"), en particular la ley $2^{a}$, pp. 393-396. El duelo ya había sido duramente castigado desde los reinados de Felipe V y Fernando VI.

52 Código penal de España, sancionado por S.M. en 19 de mayo de 1848, y reformado según el real decreto de 30 de junio de 1850, op. cit., pp. 89-90; Código penal reformado por ley de 17 de junio de 1870, op. cit., pp. 119-121.

53 Dona T. Andrew, "The Code of Honour and its Critics: The Opposition to Duelling in England, 1700-1850”, Social History, 5.3, 1980, pp. 408-434 y Stephen Banks, A Polite Exchange of Bullets. The Duel and the English Gentleman, 1750-1850, Boydell, Woodbridge, 2010.

54 Julio Ponce Alberca y Diego Lagares García, Honor de oficiales: los tribunales de honor en el ejército de la España contemporánea (siglos XIX-XX), Carena, Barcelona, 2000.

55 Miguel Martorell Linares, Duelo a muerte en Sevilla: una historia española del novecientos, Centro de Estudios Andaluces/Ediciones del Viento, Sevilla/Coruña, 2016.

56 Diario de Sesiones del Congreso de los Diputados, 13 de febrero de 1902, pp. 3424-3433. 
estos politicos chocaron con la mentalidad que hemos ido viendo en estas páginas, que consideraba que el respeto al honor entre las elites era algo individual, privado, al margen de las leyes. Incluso algunos miembros de las ligas antiduelistas se hallaban persuadidos de estas ideas cuando pedian al Estado leyes especiales que ofrecieran garantías en la protección del honor para evitar los desafios ${ }^{57}$.

\section{CONCLUSIONES}

Los casos aquí analizados nos muestran la actividad del Estado como mediador en la regulación de los conflictos sobre el honor a través de las distintas instancias judiciales implicadas. La disconformidad de los individuos con los resultados de las sentencias emitidas en primera instancia derivó en recursos de casación que se ventilaron en el Tribunal Supremo. Todo ello nos indica un proceso de interiorización de los principios de legalidad en la resolución de estos conflictos. Es decir, asistimos a la aceptación del papel del Estado como intermediario en la vida cotidiana de la ciudadanía. A la vez, hemos visto cómo los tribunales trataron de hacer compatible tanto la libertad de expresión verbal y escrita con el respeto a la reputación personal, con las dificultades que ello entrañaba. A través de leyes especiales y, posteriormente, de la canalización de los conflictos a través del derecho común, se trató de buscar un inestable equilibrio entre la defensa de dos derechos que estaban llamados a colisionar. Una buena parte de la población asumió los procedimientos judiciales para dirimir sus disputas porque la justicia permitia la publicidad del proceso de limpieza de su imagen pública. El trato con las instituciones judiciales no era algo frecuente en la vida cotidiana de la mayor parte de la población, por lo que iniciar un proceso judicial podía alcanzar un cierto eco en el entorno más próximo a la persona, de modo que esta se hallaba en disposición de mostrar públicamente su reacción ante el carácter calumnioso o injurioso de las acusaciones vertidas contra él. Esta acción adquiría ya de por sí un carácter performativo que contribuía, en una cierta medida, a limpiar la propia reputación. En el caso de las mujeres, una acción de este tipo permitía tomar una iniciativa que les estaba vedada en otros ámbitos. Se producía, por tanto, la peculiar situación de que la mujer defendia un concepto tradicional del honor, que tenía en el mantenimiento de la virtud sexual su objetivo prioritario, mediante procedimientos establecidos por un estado moderno que le garantizaba el ejercicio de sus derechos civiles a la vez que le negaba sus derechos políticos.

De forma paralela, el afianzamiento de la justicia como instrumento para la defensa del honor se vio limitado por la subsistencia de unas pautas morales apoyadas en un código del honor sentido, percibido y vivido como privativo de unas elites masculinas que no aceptaban lo que consideraban una intromisión en su espacio más íntimo: la defensa del honor. La demanda de creación de jurisdicciones especiales, como los tribunales de honor, pretendia construir una legalidad paralela a la común del resto de la ciudadanía, estableciendo entre los

57 Tomás Escriche, "Razones que imponen la absoluta desaparición del duelo", conferencia impartida en el Ateneo Barcelonés el 26 de abril de 1911, en Liga Antiduelista Española. Comité de Cataluña. Contribución a la campaña de Propaganda antiduelista en España, Imp. de Pedro Ortega, Barcelona, 1911, p. 43. De hecho, la entidad internacional que agrupaba a las ligas antiduelistas incluía en su denominación esta demanda pues su nombre era "Union internationale contre le duel et pour la protection de l'honneur". 
individuos unas diferencias incompatibles con los principios constitucionales de los estados liberales. Por otra parte, la dilación en la reparación de la propia reputación que implicaban los procedimientos judiciales, un mal señalado por muchos contemporáneos, no contribuía en nada a erradicar estas ideas de la mentalidad de las elites. Ello explica no ya la continuidad, sino el gran auge que tuvo la práctica del duelo en el siglo XIX. Pervivencia del Antiguo régimen o expresión de nuevas formas de elitismo en una sociedad tendente al igualitarismo, el duelo aparece como un fósil del pasado que logró actualizarse en el siglo de las revoluciones liberales ${ }^{58}$.

\section{BIBLIOGRAFÍA}

Álvarez Martínez, Cirilo, Ensayo histórico-filosófico-legal sobre el duelo, La Ilustración, Madrid, 1847.

Andrew, Dona T., "The Code of Honour and its Critics: The Opposition to Duelling in England, 1700-1850”, Social History, 5.3, 1980, pp. 408-434.

Aresti, Nerea, Médicos, donjuanes y mujeres modernas: los ideales de feminidad $y$ masculinidad en el primer tercio del siglo $X X$, Universidad del País Vasco, Bilbao, 2001.

Banks, Stephen, A Polite Exchange of Bullets. The Duel and the English Gentleman, 1750-1850, Boydell, Woodbridge, 2010.

Bowman, James, Honor. A History, Encounter Books, Nueva York, 2006.

Burdiel, Isabel y Pol Dalmau i Palet, La imagen pública del poder. Escándalos y causas célebres en Europa (siglos $X I X-X X)$, Historia y política: Ideas, procesos y movimientos sociales, $\mathrm{n}^{\circ} 39,2018$.

Castro Alfin, Demetrio, Los males de la imprenta. Politica y libertad de prensa en una sociedad dual, Centro de Investigaciones Sociológicas, Madrid, 1998.

Castro Orozco, José y Manuel Ortiz de Zúñiga en su libro Código Penal reformado, con el texto ajustado a la nueva edición oficial y con anotaciones y observaciones sobre las reformas y sus motivos, Imprenta de Santiago Saunaque, Madrid, 1850.

Código penal de España, sancionado por S.M. en 19 de mayo de 1848, y reformado según el real decreto de 30 de junio de 1850, Manuel Aurí, Barcelona, 1850.

Código penal de España, sancionado por S.M., enmendado con arreglo a los reales decretos de 21 y 22 de septiembre de 1848 y comentado por D.J.S. y D.A. de B., abogados de los tribunales del Reino y del Ilustre Colegio de esta ciudad, Imprenta de D. Ramón Martín Indar, Barcelona, 1848.

Código penal español, decretado por las Cortes en 8 de junio, sancionado por el Rey y mandado promulgar en 9 de julio de 1822, Imprenta Nacional, Madrid, 1822.

Código penal reformado por ley de 17 de junio de 1870 que autoriza su planteamiento provisional comparado con el de 30 de junio de 1850 y comentado en

58 Este trabajo forma parte del proyecto de investigación "Cultura del honor, politica y esfera pública en la España liberal (1833-1890)" (PGC2018-093698-B-I00), financiado por el Ministerio de Ciencia, Innovación y Universidades/FEDER. 
algunos puntos por don Celestino Mas y Abad, abogado de los tribunales, Imprenta y Estereotipia de M. Rivadeneyra, Madrid, 1870.

Corbin, Alain (dir.), Histoire de la virilité. 2. Le triomphe de la virilité. Le XIXe siècle, Seuil, París, 2011.

Diario de Sesiones. Congreso de los Diputados. Serie histórica (https://app.congreso.es/est_sesiones/)

Escriche, Tomás, "Razones que imponen la absoluta desaparición del duelo", en Liga Antiduelista Española. Comité de Cataluña. Contribución a la campaña de Propaganda antiduelista en España, Imp. de Pedro Ortega, Barcelona, 1911.

Felipe Redondo, Jesús de, "Masculinidad y movimiento obrero español: las identidades masculinas obreras y el trabajo femenino, 1830-1870", Historia, trabajo y sociedad, $\mathrm{n}^{\circ} 8,2017$, pp. 65-85.

Fernández Sarasola, Ignacio, “Opinión pública y 'Libertades de expresión' en el constitucionalismo español (1726-1845)", Historia constitucional: Revista Electrónica de Historia Constitucional, n ${ }^{\circ}$ 7, 2006.

Fiestas Loza, Alicia, Los delitos politicos (1808-1936), Universidad de Salamanca, Salamanca, 1977.

Frevert, Ute, Men of Honor. A Social and Cultural History of the Duel, Wiley, Londres, 2007 (1995).

Gaceta de Madrid (https:/ / www.boe.es/buscar/gazeta.php)

Groizard y Gómez de la Serna, Alejandro, El Código penal de 1870 concordado y comentado por D. (Alejandro) Groizard y Gómez de la Serna, tomo V, Esteban Hermanos impresores, Salamanca, 1894.

Guillet, François, "La tyrannie de l'honneur. Les usages du duel dans la France du premier XIXe siècle”, Revue historique, n 640, 2006/4, pp. 879-899.

Hidalgo García, Juan Antonio, El Código Penal conforme a la doctrina establecida por el Tribunal Supremo, Imp. de la Revista de Legislación, Madrid, 1909, vol. II.

Luengo López, Jordi, "Masculinidad reglada en los lances de honor: desafios burgueses en el cénit de un fin de época (1870-1910)", Rúbrica contemporánea, vol. $7, \mathrm{n}^{\circ} 13,2018$, pp. 59-79.

Maiza Ozcoidi, Carlos, "La definición del concepto del honor. Su entidad como objeto de investigación”, Espacio, Tiempo y Forma, Serie IV, t. 8, 1995, pp. 191209.

Martorell Linares, Miguel, "Un duelo en 1900: Un 'delito especial”, en Javier Alvarado Planas, Miguel Martorell (coords.), Historia del delito y del castigo en la Edad Contemporánea, UNED/Dykinson, Madrid, 2017.

Martorell Linares, Miguel, Duelo a muerte en Sevilla: una historia española del novecientos, Centro de Estudios Andaluces/Ediciones del Viento, Sevilla/Coruña, 2016.

Mateos Fernández, Juan Carlos, "Cuestión de honor. Los periodistas se baten en duelo", Historia y comunicación social, n 3, 1998, pp. 323-342.

Mira Benavent, Jaime, Los limites penales a la libertad de expresión en los comienzos del régimen constitucional español, Tirant lo Blanc, Valencia, 1995. 
Mosse, George L., The image of man: the creation of modern masculinity, Oxford University Press, Oxford, 1996.

Novisima Recopilación de las leyes de España, [s.i.], Madrid, 1807, tomo V.

Ortega del Cerro, Pablo, "Del honor a la honradez: un recorrido por el cambio de valores sociales en la España de los siglos XVIII y XIX”, en Cuadernos de Ilustración y Romanticismo, n 24, 2018, pp. 597-618.

Pablo Serrano, Alejandro de, Los delitos contra el honor en el derecho penal español y en el derecho comparado, Universidad de Valladolid, Valladolid, 2014.

Pacheco, Joaquín Francisco, El Código penal concordado y comentado, Imprenta de la Viuda de Perinat y Compañia, Madrid, 1856 (2 edición), vol. 1.

Pitt-Rivers, Julien, Antropología del honor o politica de sexos. Ensayos de antropología mediterránea, Crítica, México D.F., 1979.

Ponce Alberca, Julio y Diego Lagares García, Honor de oficiales: los tribunales de honor en el ejército de la España contemporánea (siglos XIX-XX), Carena, Barcelona, 2000.

Sánchez, Raquel, "Honor de periodistas. Libertad de prensa y reputación pública en la España liberal", en Raquel Sánchez y José Antonio Guilllén Berrendero (eds.), La cultura de la espada. De honor, duelos y otros lances, Dykinson, Madrid, 2019, pp. 305-332.

Sánchez, Raquel, " 'El duelo es una necesidad de los tiempos presentes'. Opiniones sobre el carácter civilizador del duelo en la España del siglo XIX", Memoria y Civilización, $\mathrm{n}^{\circ}$ 23, 2020, pp. 1-21.

Sanz, Adelardo, Esgrima del sable y consideraciones sobre el duelo, Imprenta de Fortanet, Madrid, 1886.

Sierra, Maria, "Entre emociones y politica: la historia cruzada de la virilidad romántica”, Rúbrica Contemporánea, vol. 4, n 7, 2015.

Sohn, Anne-Marie, "Sois un Homme!" La construction de la masculinité au XIXe siècle, Seuil, París, 2009.

Stewart, Frank Henderson, Honor, University of Chicago, Chicago/Londres, 1994.

Taylor, Charles, Fuentes del yo. La construcción de la identidad moderna, Paidós, Barcelona, 2006.

Tosh, John, Manliness and Masculinities in Nineteenth Century Britain: essays on gender, family, and empire, Routledge, Londres, 2016 (2005).

Viada y Vilaseca, Salvador, Código penal reformado de 1870: con las variaciones introducidas en el mismo por la ley de 17 de julio de 1876: concordado y comentado, Imp. de Manuel G. Hernández, Madrid, 1885.

Welsh, Alexander, What is Honor? A Question of Moral Imperatives, Yale University Press, New Haven/Londres, 2008.

Enviado el (Submission date): 11/04/2019

Aceptado el (Acceptance date): 23/06/2019 